\title{
Göç, İşsizlik ve Gelir Arasındaki İlişkilerin Analizi: OECD Ülkeleri Örneği*
}

Araştırma Makalesi /Research Article

\author{
Mustafa KÖSEOĞLU ${ }^{1}$ \\ Gamze ARTAN ${ }^{2}$
}

ÖZ: Küreselleşme hareketleriyle birlikte özellikle 2000'li yıllardan sonra büyük artış gösteren uluslararası göç hareketleri, günümüzde yüksek gelirli ülkeler için en önemli ekonomik ve politik konuların başında gelmektedir. Bu çalışmada, göçün makroekonomik belirleyicilerinin neler olduğunu ortaya koymak amacıyla göç, işsizlik ve kişi başına düşen gelir arasındaki ilişkiler 20002016 döneminde panel veri analiz yöntemi kullanılarak 27 OECD ülkesi için test edilmiştir. Çalışmadan elde edilen sonuçlara göre, işsizlik oranı göç üzerinde negatif ve \%1 seviyesinde istatistiksel olarak anlamlı bir etkiye sahip olup işsizlik oranında meydana gelen \% 1 'lik artış, OECD ülkelerinde bu ülkelere gelen göçü yaklaşık \% 0,3 azaltmaktadır. Kişi başına düşen gelir göç üzerinde pozitif ve \%1 seviyesinde istatistiksel olarak anlamlı bir etkiye sahip olup kişi başına düşen gelirin $\% 1$ oranında artması, OECD ülkelerine gelen göçü yaklaşık \%1 oranında artırmaktadır. Çalışmadan elde edilen bu sonuçlar, göçün belli kanunlar çerçevesinde bir ülkeden diğerine gitmediğini her ülkenin kendine özgü koşullarının göç akımlarını etkilediğini ortaya koymaktadır. Dolayısıyla, politika uygulayıcılarının ülkelerine özgü bireysel özellikleri dikkate alarak politika geliştirmeleri önem arz etmektedir.

Anahtar Kelimeler: Göç, İşsizlik, Gelir, OECD Ülkeleri, Panel Veri Analizi JEL Kodları: F22, E24, J61, C33

\section{Analysis of Relations between Migration, Unemployment and Income: The Case of OECD Countries}

\begin{abstract}
International migration flows that especially have risen after the 2000s with globalization movements is one of the major economic and political concerns for high income countries these days. In this study, in order to assert the macroeconomic determinants of migration, the relationship between migration, unemployment and per capita income in 2000-2016 period is analyzed by using panel data analysis for 27 OECD countries. According to the test results, unemployment rate has $1 \%$ negative and statistically significant effect on migration and $1 \%$ of unemployment rate rise results in about a $0,3 \%$ decrease of migration to OECD countries. Per capita income has $1 \%$ positive and statistically significant effect on migration, and $1 \%$ of per capita income rise results in about a $1 \%$ increase of migration to OECD countries. The results suggest that migration does not mean to move from one country to another according to certain rules, but the special conditions of each country effect migration flows. Therefore, it is important that policy makers should convey politics considering the properties typical to their own countries.
\end{abstract}

Keywords: Migration, Unemployment, Income, OECD Countries, Panel Data Analysis JEL Codes: F22, E24, J61, C33

Geliş Tarihi / Received: 07/01/2020

Kabul Tarihi / Accepted: 25/02/2020

\footnotetext{
*Bu çalışma, Gamze Artan'ın “Göç, İşsizlik ve Gelir Arasındaki İlişkilerin Analizi: OECD Ülkeleri Örneği” başlıklı yüksek lisans tezinden üretilmiştir.

${ }^{1}$ Prof. Dr. Karadeniz Teknik Üniversitesi, İ̈BF, Ekonometri Bölümü, mkoseoglu@ @tu.edu.tr, orcid.org/00000003-1542-4271.

${ }^{2}$ Uzman, Türkiye Vakıflar Bankası, Trabzon Şubesi, gamzekolayli@gmail.com, orcid.org/0000-0003-10997900 .
} 


\section{Giriș}

Göç özellikle yüksek gelirli ülkeler için önemli ekonomik ve politik konuların başında gelmektedir. Birleşmiş Milletler Dünya Göç Raporu (2018) verilerine göre iki yüz yetmiş milyon (dünya nüfusunun yaklaşık \%3.6's1) doğduğu ülkelerin dışındaki ülkelerde yaşamaktadır. Araştırmacılar bu sürecin devam etmesi durumunda önümüzdeki on yıl içinde bu oranın yaklaşık $\% 5$ seviyelerine çıkacağını ileri sürmektedirler. Bu durum, göç olgusunun önümüzdeki y1llarda özellikle yüksek gelirli ülkeler olmak üzere tüm dünyada önemli bir problem olarak devam edeceğini göstermektedir. Kuşkusuz göçler ekonomiler üzerinde sadece olumsuz etkiler doğurmamakta özellikle yeteneklerini/birikimlerini gösteremedikleri ülkelerden göç edenler ve işgücü eksikliği çekilen ülkelere giden göçmenler gittikleri ülkelerin ekonomilerine pozitif olarak katkı yapmaktadırlar. Dünyanın her yerinde bireyler daha iyi iş bulabilme, daha yüksek ücret elde etmek daha iyi yaşam koşullarına ulaşmak, yoksulluk, zulüm ve şiddetten kurtulmak ve benzeri nedenlerle uluslararası göçü tercih etmektedirler. Ayrıca siyasi istikrarsızlıklar, nüfusun fazla olması, eğitim sistemlerindeki farklılıklar, ticari imkanlar ve çevresel faktörler insanların göç etme kararlarında etkili olmaktadır.

Göçün arkasında yatan etmenlerin farklı olması göçü disiplinler arası bir olgu haline getirmektedir. Günümüzde göçlerin nedenleri sosyoloji, ekonomi, coğrafya ve siyaset bilimi gibi farklı disiplinler tarafından araştırılmaktadır. Çünkü uluslararası göç sadece göç eden bireyleri, göç alan ve göç veren ülkeleri değil, toplumlarda ekonomik, sosyal, kültürel, çevresel, demografik ve toplumsal dinamikleri de etkilemektedir. Bu nedenle uluslararası göçün belirleyicileri ve etkileri literatürde sıklıkla tartışılmaktadır. Örneğin Borjas (2001), Bonin (2005) ve Steinhardt (2011), göçlerin işgücü piyasası üzerindeki etkilerini ve esas itibari ile göçlerin yerel işgücünün ücretlerinde bir değişim yaratıp yaratmadığını araştırmışlardır. Bir diğer çalışmada Grogger ve Hanson (2011), eğitim seviyesi ve ücret farklılıklarının göç üzerindeki etkilerini OECD ülkeleri için analiz etmişlerdir. Mayda (2007), gelir eşitsizliğinin ülkeler arasındaki göç akımları üzerindeki etkilerini analiz etmiştir. Lewer ve Berg (2008), Ortega ve Peri (2009), Kim ve Cohen (2010), göçün arakasında yatan demografik, coğrafik ve sosyal faktörleri panel çekim modelini kullanarak test etmiştir. Öte yandan Karemera vd. (2000), Neumayer (2005), dil, kültür ve ortak tarihsel geçmişin göç üzerindeki etkilerini analiz etmiştir. Docquier vd. (2011b) ücret farklılıklarının, Docquier vd. (2011a), demokrasinin göç üzerindeki etkilerini test etmişlerdir.

Literatürdeki çalışmalar bir bütün olarak incelendiğinde genel itibariyle göç olgusunun ekonomik, coğrafi, kurumsal ve kültürel boyutlarıyla ayrı ayrı analiz edildiği ve dolayısıyla ulaşılan sonuçların incelenen alana göre farklılaştığ görülmektedir. Bu nedenle göçün etkileri konusunda teorik yaklaşımlarda olduğu gibi ampirik analizlerde de bir uzlaşı yoktur.

Göçmenler gittikleri ülkelerin temel makroekonomik göstergelerini büyük ölçüde etkilediği gibi gittikleri ülkelerin temel makroekonomik göstergelerinden de 
etkilendiği bilinmektedir. Dolayısıyla bu çalışmada göç üzerinde etkili olduğu bilinen coğrafi, kültürel ve kurumsal değişkenlerden ziyade temel makroekonomik göstergelerin göç için iten faktör mü yoksa çeken faktör mü olduğu araştırılmıştır. Kısaca bu çalışmanın amacı, dünyada oransal olarak en fazla göç alan OECD ülkelerinde işsizlik ve kişi başına düşen gelirin göçü nasıl etkilediğini panel veri analiz yöntemini kullanarak ortaya koymaktır. Bu amaçla, yatay kesit bağımlılığını dikkate alan birim kök, eşbütünleşme ve AMG testleri kullanılarak hem grup olarak 27 OECD ülkesinde göç, işsizlik ve gelir arasındaki ilişkiler tahmin edilmiştir.

Göçün altında yatan temel makroekonomik göstergelerden işsizlik ve gelir tarafından nasıl etkilendiğinin belirlenmesi yani işsizlik oranı ve kişi başına düşen gelirin göç için iten bir faktör mü yoksa çeken bir faktör mü olduğunun ortaya konması ilgili alanda çalışan araştırmacılara ve politika uygulayıcılarına yol gösterici olması beklemektedir.

Çalışmanın ikinci bölümünde göç teorilerine yer verilmiş, göçlerin ekonomik etkilerine ilişkin literatürün yer aldığı üçüncü bölümü ekonometrik yöntem ve analiz sonuçlarının yer aldığ 1 üçüncü bölüm takip etmiştir. Son kısımda çalışmanın genel bir değerlendirilmesi yapılmış ve politika önerilerine yer verilmiştir.

\section{Göç Teorileri}

Göç tarihi oldukça eski olmakla birlikte göçlerin belirleyicilerini tüm yönleriyle ortaya koyan bir teori henüz geliştirilememiştir. Sosyologlar, coğrafyacılar, politikacılar ve iktisatçılar göçün belirleyicilerinin neler olduğu konusunda farklı görüşlere sahiptirler. Göç hareketlerini açıklayan ilk teori olma özelliğine sahip coğrafyacı Ravenstein (1885)'in göç teorisi, göçü, doğa bilimlerine uyarlamaya çalışmakta ve göçlerin belirleyicilerinin tesadüfü değil belirli kanunlar çerçevesinde gerçekleştiğini ileri sürmektedir. Buna göre, göçlerin arkasında yatan temel unsur coğrafi olup bireylerin genel kısa mesafeli yerlere göç edeceğini, göçün kırsal kesimden büyük ticaret merkezlerine doğru olacağını, kırsalda yaşayanların kentte yaşayanlara kıyasla daha fazla göç edeceğini ve benzer şekilde kadınların erkeklere kıyasla daha fazla göç edeceğini ileri sürmektedir. Ravenstein (1885) göç teorisi sadece iç göçü açıklaması ve açıklamalarını doğa kanunlarına uyarlaması nedeniyle eleştirilse de sonraki yıllarda çok sayıda göç teorisinin geliştirilmesine de ön ayak olduğu açıktır.

Ravenstein (1885) göç teorisindeki uzaklık unsurunu Newton'un çekim yasasına uyarlayarak göçü açıklayan bir diğer göç teorisi Zipf (1946) tarafından ortaya atılmıştır. Zipf (1946) Newton'un çekim yasasından yola çıkarak göçün ülkeler arasındaki uzaklık ile ters orantılı ülkelerin nüfus büyüklükleri ile doğru orantılı olduğunu ileri sürmüştür. Buna göre, ülkeler arasındaki uzaklık arttıkça göç akımları da yavaşlayacaktır. Teori göçün arakasında yatan sosyolojik, psikolojik faktörleri dışarıda tutup göçü sadece ülkeler arasındaki uzaklık farklılıklarına indirgediği için eleştirilmektedir. 
Göçün belirleyicilerini açıklamak amacıyla ortaya atılan ve literatürde sıklıkla başvurulan bir diğer yaklaşım "itme" ve "çekme" faktörlerine vurgu yapmakta olup Lee (1966) tarafından geliştirilmiştir. Lee (1966)' ya göre, ülkelere özgü faktörlerin bir kısmı bireyleri göç etmeye iterken bir kısım faktörler göç etmek isteyen bireyleri kendisine çekmek için cazip koşullar sunmaktadır. Ancak bu iten ve çeken faktörler herkes için aynı olmayıp bireyden bireye değişkenlik göstermektedir. Dolayısıyla göç olayı bireyin iten faktörler ve çeken faktörler karşısında vermiş olduğu kararın bir sonucu olarak gerçekleşmektedir. Teori demografik, çevresel ve ekonomik faktörlerin göçe sebep olduğunu varsaydığı diğer sosyal, politik ve kurumsal faktörleri dışladığı için eleştirilmektedir.

Göçü sosyolojik faktörlerle açıklayan Stouffer (1940)'e göre, belirli bir mesafeye göç edenlerin sayısı, bu mesafedeki firsatların sayısı ile doğru orantılı ve kesişen firsatların sayısı ile ters orantılidır. Stouffer (1940), Ravenstein (1885)'den farklı olarak göç ile uzaklık arasındaki ilişkiye değil göç ile firsatlar arasındaki ilişkiye odaklanmaktadır. Diğer göç teorilerinde olduğu gibi Stouffer (1940) göç teorisi de göçe sadece sosyolojik açıdan bakmakta dolayısıyla göçün altında yatan diğer etmenleri dışlamaktadır. Göç olayına sosyolojik açıdan bakan bir diğer yaklaşım Petersen (1958) tarafından ortaya atılmıştır. Petersen (1958) göçleri ilkel, zorunlu, yönlendirilmiş, serbest ve kitlesel göç şekilde sınıflandırmak suretiyle genel göç teorisini geliştirmeye çalışmıştır. Petersen (1958) göç teorisi itme ve çekme teorisi gibi birkaç teoride öne sürülen unsurları birleştirmeye çalışsa da göçü tüm yönleriyle ortaya koyamadığı için eleştirilmektedir.

Göçlerin belirleyicilerin neler olduğu konusundaki tartışmalara iktisatçılar da ilgisiz kalmamış ve göçlerin belirleyicilerine ilişkin biri dizi teori geliştirmişlerdir. Hatta göçlerin belirleyicilerine ilişkin ilk kanıtların iktisat biliminin kurucusu Adam Smith'in 1776'da yayınladığı ünlü eseri "Milletlerin Zenginliği”" adlı kitapta olduğu göze çarpmaktadır. Ancak göçün belirleyicilerine ilişkin ilk kapsamlı yaklaşım 1950'li yıllarda geliştirilmiş olup literatürde Neoklasik göç teorisi olarak bilinmektedir. Daha sonraki yıllarda Neoklasik göç teorisinin temel varsayımlarının güncel gerçeklerle uyuşmadığını ileri süren ve Neoklasik göç teorisini geliştiren/tamamlayan çok sayıda göç teorisi ortaya atılmıştır. İktisadi anlamda göç teorileri esas itibariyle üç soruya cevap aramaktadırlar: Neden göç ediliyor? Kim göç ediyor? Göçün kaynak ve hedef ülkeye olan etkileri nelerdir? Bu sorulara verilen yanıtlar teoriden teoriye değişmekte ve yukarıda ana hatlarıyla özetlenen göç teorilerinde olduğu gibi iktisadi açıdan olaya bakan göç teorileri de göçün belirleyicilerine ilişkin göçün arakasında yatan tüm etmenlerin neler olduğunu ortaya koymaktan uzak kalmıştır.

Göç teorilerinin yanı sıra bu teorilerin istatistiklere yansımasının ne düzeyde olduğunu tespit etmek amaciyla dünyada ve OECD ülkelerindeki göç istatistikleri incelenmiştir. Birleşmiş Milletler Uluslararası Göç Raporu (2017)'ye göre, dünyada göç stoku miktarı 1990 yılında 153 milyon iken bu rakam 2000, 2010 ve 2017 yıllarında sırasıyla 173 milyon, 220 milyon ve 258 milyon kişiye çıkmıştır. 
2000-2017 döneminde göç stoku en fazla artan bölgeler sırasıyla Afrika, Asya ve Okyanusya iken göç stoku en az artan bölgeler ise sırasıyla Avrupa ve Kuzey Amerika olmuştur.

Göç stoku gelir grupları açısından incelendiğinde yüksek gelirli ülkelerdeki göç stoku 1990 yılında 75 milyon iken bu rakam 2000, 2010 ve 2017 yıllarında sirasiyla 100 milyon, 142 milyon ve 165 milyon kişiye çıkmıştır. Yani 2017 yılı itibariyle dünya göç stokunun yaklaşık \%64'ü yüksek gelirli ülkelerde yaşamakta iken $\% 31$ 'lik kısmı orta gelirli ülkelerde ve \%4'lük kısmı düşük gelirli ülkelerde yaşamaktadır. Bu istatistikler ülkelerin gelir seviyelerinin göç için önemli bir çekme faktörü konumunda olduğunu göstermektedir. $\mathrm{Bu}$ sonuç, dünyada gelişmiş ülkelerin nispeten sermaye zengin ülke olmaları ve daha fazla işgücüne ihtiyaç duymalarından kaynaklanmaktadır. $\mathrm{Bu}$ istatistiki bilgi ampirik analizin motivasyonunu oluşturan temel faktörlerden biri olmuş ve istatistiki bilgiler ampirik analizle test edilmiştir. Bölgelere göre göç istatistikleri incelendiğinde ise dikkat çeken bir diğer bulgu 2017 yılı itibariyle Asya ve Afrika bölgesi dişarıda tutulduğunda kadınların erkeklere kıyasla daha fazla göç ettiğinin tespit edilmesidir. Bu sonuç, Ravenstein (1885)' in kadınlar erkeklere göre daha fazla göç eder şeklindeki göç kanununu destekler niteliktedir.

\section{Göçlerin Ekonomik Etkilerine İlişkin Literatür}

Göçlerin ekonomik etkilerine ilişkin literatürde çok sayıda çalışma mevcuttur. Bu çalışmaların bir kısmı Mayda (2007), Kim ve Cohen (2010) ve Boubtane vd. (2013) göçlerin belirleyicilerinin analizine yönelmekte ve çeşitli ülkelerde göçlerin temel belirleyicilerinin neler olduğunu araştırmaktadır. Bir diğer araştırmacı grubu ise Borjas (2001), Bonin (2005) ve Steinhardt (2011), göçlerin işgücü piyasası üzerindeki etkilerine odaklanmakta ve esas itibari ile göçlerin yerel işgücünün ücretlerinde bir değişim yaratıp yaratmadığını sorgulamaktadır. Öte yandan panel çekim modelini kullanan Lewer ve Berg (2008), Ortega ve Peri (2009) ve Kim ve Cohen (2010) ülkeler arasındaki göç akımlarının belirleyicilerinin neler olduğunu araştırmaktadırlar. Panel çekim modeli sunduğu olanaklar çerçevesinde uzaklık gibi coğrafi faktörler ile ortak dil, ortak sınır gibi kültürel faktörlerin göçler üzerindeki etkileri ortaya konabilmektedir. Göç üzerine yapılan çalışmaların bir kısmı ise Shan vd. (1999), Morley (2006), Islam (2007) ve Boubtane (2013)'de olduğu gibi göç ile makroekonomik göstergeler arasındaki kısa ve uzun dönem ilişskileri ile nedensellik ilişkilerine odaklanmaktadırlar. Göçle ilgili bir diğer çalışma alanı ise Docquier vd. (2011a), Bove ve Elia (2017)'de olduğu gibi demokrasi ve özgürlükler gibi kurumsal faktörlerin göç üzerindeki etkilerini araştırmaktadır.

Göçün emek piyasası üzerine etkilerini inceleyen araştırmacılardan Borjas (2001), ABD ekonomisinde 1950-1990 yılları nüfus sayım verilerinden yararlandığı çalışmasında, göçün işgücü piyasası üzerindeki etkilerini teorik ve uygulamalı olarak araştırmıştır. Elde edilen bulgular, eğitim grupları içinde, yeni göçmenlerin 
yerli işgücü ve daha önceki göçmenlere göre yetenekleri için en yüksek getiriyi sunan eyaletlerde bulunma eğiliminde olduklarını göstermektedir.

Steinhardt (2011) çalışmasında, Almanya'daki göçün yerli işgücü piyasası üzerindeki etkilerinin incelenmesinde kullanılacak uygun yaklaşımın belirlenmesine katkıda bulunmayı amaçlamıştır. Bu amaçla İstihdam Araştırma Enstitüsü'nden (IAB) elde edilen 1975-2001 dönemini kapsayan verilerden yararlanılmıştır. Çalışmada ilk olarak, göçlerin ücret etkileri Borjas (2003) tarafından belirlenen ve Bonin (2005) tarafından kabul edilen eğitimsel kazanım ve işgücü piyasası deneyimine bağlı beceri grupları düzeyinde analiz edilmiştir. Sonuçlar, Almanya'daki göçün yerli işgücü ücretleri üzerinde olumsuz bir etkisinin olmadığını öne süren daha önceki bulguları doğrulamaktadır. Kadınlar için yapılan analizler ise göçün nispi yerel ücretler üzerinde olumsuz bir etkisi olduğunu göstermektedir. Çalışmada daha sonra, benzer eğitim ve deneyime sahip göçmenlerin ve yerli işgücünün farklı meslek dallarında çalışabilecekleri gözlemine dayanarak, analiz meslekler seviyesinde genişletilmiştir. Elde edilen bulgular, özellikle temel hizmet mesleklerindeki yerli işgücü için olumsuz ücret etkileri söz konusu olduğunu göstermektedir. $\mathrm{Bu}$ nedenle Steinhardt (2011), gelecek çalışmalarda göçmenler ve yerli işgücü arasındaki kurumsal ve sosyoekonomik farklılıkların modellenmesi gerekliliğini vurgulamaktadır.

Bonin (2005), göçün emek piyasası üzerindeki etkisini aynı eğitime fakat farklı iş tecrübesine sahip göçmenler açısından etkisini ele almıştır. Çalışmada, 1975-1997 dönemi verileri kullanılmıştır. Almanya için gerçekleştirilen analizde, ülkenin faklı bölgeleri için regresyon analizleri gerçekleştirilmiştir. Çalışmadan elde edilen sonuçlar, göçmenlerin işgücü piyasasına nüfuz etmesinin yerli işgücünün kazanç ve istihdam olanakları üzerinde negatif bir etkiye sahip olduğuna dair hipotezi desteklememektedir. Ulaşılan bu bulgulara göre, işgücü piyasasında göçmen nüfusundaki \%10'luk bir artış, ücretleri \%1'den daha az azaltmakta ve işsizliği artırmamaktadır.

Docquier vd. (2011b), OECD ülkeleri için gerçekleştirdikleri analizde iç ve dış göçün işgücü piyasası üzerindeki etkilerini ele almışlardır. Çalışmada, hedef ve kaynak ülkelerde göç edenler eğitim seviyelerine göre sınıflandırılmıştır. 19902000 döneminin ele alındığı çalışmada gerçekleştirilen analiz sonuçları, gelen göçün düşük eğitime sahip yerli vatandaşların ücretleri üzerinde pozitif ve anlamlı bir etkisi olduğunu göstermektedir. Bununla birlikte gelen göçün, yerli istihdam üzerinde anlamlı bir etkiye sahip olmadığı ve dış göçün eğitim seviyesi düşük çalışanların ücretlerini azalttı̆̆ tespit edilmiştir.

Jean ve Jimenez (2011), 1984-2003 dönemi için gelen göçün işgücü piyasasında yerli vatandaşların işsizliğini etkileyip etkilemediğini irdelemişlerdir. Çalışma, OECD ülkeleri için gerçekleştirilmiştir. Etki-tepki analizi yönteminin kullanıldığı çalışmada uzun dönemde gelen göçün yerli vatandaşların işsizliği üzerinde herhangi bir anlamlı etkisinin olmadığ 1 sonucuna ulaşılmıştır. Kısa dönemde ise bu etkinin gecikmeli olarak gerçekleşebileceği belirtilmiştir. Ancak özellikle gelen 
göçmenlerin işgücü piyasasına ilişkin kabiliyetleri yerli vatandaşlara yakınsa bu olası etkinin çok daha küçük olabileceği tahmin edilmiştir.

Dustmann vd. (2005), çalışmasında teorik tartışmalara da yer vererek göçlerin İngiltere'deki yerli işçilerin işgücü piyasası sonuçlarını nasıl etkileyebileceğini araştırmışlardır. Araştırmacılar göçün teorik altyapısının, göçmenlerin göç alan ülkenin işgücü piyasası üzerindeki etkilerini kesin olarak açıklayamadığını ileri sürmektedirler. Çalışmada göç türlerindeki muhtemel farklılıkların dikkate alınmasının elde edilen sonuçları önemli ölçüde etkilediğinin ifade edildiği çalışmada ABD ve bazı kıta Avrupa ülkelerinden farklı olarak İngiltere'ye gelen göçün sadece düşük beceriye sahip olanlardan ibaret olmadığı belirtilmektedir. 1988-2000 döneminde İngiltere ekonomisi için elde edilen sonuçlar, göçün orta eğitim seviyesine sahip olan yerel istihdamı olumsuz etkilediğini ancak diğer eğitim grupları için bunun söz konusu olmadığını ortaya koymaktadır.

Longhi vd. (2010)'un göçün işgücü piyasası üzerindeki etkilerinin araştırıldığı çalışmada, eşanlı denklem sistemlerinden üç aşamalı en küçük kareler tahmin yönteminden (3SLS) yararlanılmıştır. ABD, Avrupa ve İsrail'e ait verilerin kullanıldığ1 çalışmada elde edilen bulgular, göçmen şokunun ücret ve istihdam üzerindeki etkilerinin çok düşük düzeyde olduğunu ortaya koymaktadır. Buna göre, ev sahibi ülkenin yerel işgücü piyasasındaki göçmenlerin payındaki \% 1 puan artış yerli işgücü ücretlerini \% 0,029 oranında azaltırken yerli işgücü istihdamını \% 0,011 oranında azaltmaktadır.

Ortega ve Verdugo (2014) çalışmalarında, 1968-1999 döneminde Fransa için göçün emek piyasası üzerindeki araştırmışlardır. Göçmen sayısını hesaplamak için 1968'den 1999'a kadar olan (1968, 1975, 1982, 1990 ve 1999) Fransiz nüfus sayımından elde edilen veriler kullanılmıştır. Emek piyasası için İşgücü Anketlerinden elde edilen verilerden yararlanılmıştır. Analizler sonucu elde edilen bulgular, göçün yerli işgücü ücretleri ve istihdamı üzerindeki olumlu etkisinin bölgesel düzeyde olduğunu ortaya koymaktadır. Çalışmada göç ile yerli işgücü ücretleri ve istihdamı arasındaki pozitif korelasyonun kısmen mümkün olmasının nedeni, eğitim/deneyim gibi özellikleri açısından yerli işgücü ve göçmenler arasındaki mükemmel olmayan ikame edilebilirlik olarak vurgulanmaktadır.

Pisckhe ve Velling (1997), gelen göç oranındaki artış ile Alman asıllı vatandaşların istihdam çıktıları arasındaki ilişkiyi Almanya için ele almışlardır. Almanya işgücü piyasası 167 ayrı bölgeye ayrılarak analiz gerçekleştirilmiş ve çalışmada 1985-1989 dönemi verileri kullanılmıştır. Çalışmada göç oranın istihdam çıktısı üzerindeki etkisi regresyon analizi ile araştırılmıştır. Çalışmada esas itibariyle göçmenler ile Alman asıllı vatandaşların işgücü piyasasındaki ikame derecesi analiz edilmiştir. Elde edilen bulgular, Almanya'ya gelen göçün Alman asıllı vatandaşların istihdamını etkilediğine dair direkt bir kanıt ortaya koyamamıştır.

Mayda (2007), bir ülkeye gelen göçün belirleyicilerini 14 OECD ülkesi için incelemiştir. Çalışmada bu ilişki 1980-1995 dönemi için ele alınmıştır. Hedef ülke 
ve kaynak ülke için ortalama gelir ve gelir dağılımının göç üzerindeki etkileri araştırılmıştır. Bunun yanı sıra çalışmada coğrafi ve kültürel faktörlerin de hedef ülkedeki göç politikaları üzerindeki tartışma çalışmanın konularından birini oluşturmaktadır. Buna göre ulaşılan bulgular, uluslararası göç modelinin öngörüleriyle tutarlıdır. Yani, gelir seviyesindeki artışlar, bir ülkeye gelen göç oranlarını pozitif ve anlamlı bir şekilde etkilemektedir. Ayrıca, genç nüfusun toplam nüfus içindeki payı da bir ülkeye gelen göçün önemli belirleyicilerinden birisidir.

Di Maria ve Lazarova (2012), nitelikli göçün beşeri sermaye ve ekonomik büyüme üzerindeki etkisini gelişmekte olan ülke örneklemi için incelemişlerdir. Analizlerde 1990-2000 yıllarını kapsayan dönemde toplam 130 ülke örneklemi kullanılmıştır. Bunlardan 34'ü düşük gelirli, 47'si düşük orta gelirli, 34'ü yüksek orta gelirli ve 14 'ü OECD üyesi olmayan ülkelerden oluşmaktadır. En küçük kareler yöntemi (EKK) ve simülasyon analizlerinin kullanıldığı çalışmada elde edilen bulgular, göç oranının hem beşeri sermaye hem de beşeri sermaye bileşenleri üzerinde anlamlı etkilere sahip olduğunu ortaya koymaktadır. Çalışmada ayrıca örneklemi oluşturan ülkelerin \%70'inin nitelikli göç sonucu daha düşük büyümeye maruz kaldığ 1 ve bu durumun teknolojik gelişmenin düşük olduğu ülkelerde yoğunlaştı̆̆ vurgulanmaktadir.

Shan vd. (1999), göç ve işsizlik arasındaki ilişkiyi önemli ölçüde göç alan ülkelerden olan Avustralya ve Yeni Zelanda için araştırmışlardır. Toda ve Yamamoto (1995) tarafından geliştirilen Granger nedensellik testinin kullanıldığı çalışmada, 1983:3 ve 1995:4 dönemini kapsayan üç aylık zaman serisi verilerinden yararlanılmıştır. Yapılan analizler sonucu elde edilen bulgulara göre, göç ve işsizlik değişkenleri arasında nedensellik ilişkisi tespit edilememiştir. Çalışmada ayrıca işsizlik ile kapasite kullanım oranı ve işsizlik ile Stoikov ve HDB endeksleri tarafından ölçülen endüstriyel yapısal değişiklikleri arasındaki nedensellik ilişkileri de araştırılmıştır. Bulgular, kapasite kullanım oranı ve göç arasında çift yönlü, Stoikov ve DHB endekslerinden işsizliğe doğru ise tek yönlü bir nedensellik ilişkisini ortaya koymaktadır.

Morley (2006)'in çalışmasında, göç ve kişi başına ekonomik büyüme arasındaki nedensellik ilişkisi araştırılmıştır. 1930-2002 dönemi yıllık verilerinin kullanıldığı çalışmada, ARDL yöntemi kullanılmıştır. Çalışmanın örneklemi yüksek düzeyde göç alan Avustralya, Kanada ve ABD'den oluşmaktadır. Analizler sonucu elde edilen bulgular, uzun dönemde kişi başına ekonomik büyümeden göçe doğru bir nedensellik ilişkisinin bulunduğunu ancak tersinin söz konusu olmadığını göstermektedir. Morley (2006)'e göre bu sonuç; Avustralya, Kanada ve ABD'de göçü kontrol altına almak için getirilen çeşitli mevzuatların tamamen başarılı olamadığını ortaya koyabilir.

Islam (2007) göçün işsizlik, reel GSYH ve reel ücretlerle ilişkisini ele almıştır. Çeyrek dönemlik verilerin kullanıldığı çalışmada 1961: 1-2002: 1 periyodu ele alınmıştır. Göç, işsizlik, reel GSYH ve reel ücretler arasındaki ilişkiler çalışmada 
kısa dönemli ve uzun dönemli olarak Granger nedensellik analizi ve eş bütünleşme testleri ile irdelenmiştir. Yapılan Granger nedensellik analizi ve hata düzeltme modeli sonuçları, kısa dönemde işsizliğin gelen göçü azalttığını ancak tersi bir durumun geçerli olmadığını ortaya koymaktadır. Ayrıca çalışmada uzun dönemde reel GSYH, göç ve reel ücretler arasında pozitif ve anlamlı bir ilişki tespit edilmiştir. Son olarak, analiz eş bütünleşme analizi sonuçları uzun dönemde göçün işsizliği etkilemediğini göstermektedir.

Göç, işsizlik ve GSYH arasındaki nedensellik ilişkilerini inceleyen bir diğer çalışmada Boubtane vd. (2013), 22 OECD ülkesi için panel veri analiz yöntemini kullanmıştır. Analize konu olan her bir ülkeye özgü nedensellik ilişkilerinin ortaya konabilmesi için çalışmada Konya (2006), nedensellik testi tercih edilmiştir. Konya (2006) nedensellik testi sonuçlarına göre, sadece Portekiz'de işsizlik ile göç arasında negatif bir nedensellik ilişkisi tespit edilmiştir. Portekiz dışında hiçbir ülkede göç ile işsizlik arasında nedensel bir ilişki bulunamamıştır. Öte yandan, analiz sonuçları analize konu olan 22 OECD ülkesinden sadece Fransa, İzlanda, Norveç ve Birleşik Krallıkta büyümeden göçe doğru pozitif bir nedensellik ilişkisi tespit edilmiştir. Araştırmacılar, çalışmadan elde edilen sonuçların göç akımlarının yerel halkın istihdam beklentilerine zarar vermediğini ortaya koyduğunu ifade etmektedirler. Bu sonuçtan yola çıkarak araştırmacılar, yaşlanan nüfus sorunuyla mücadele etmek için birçok OECD ülkesinin göçü işçi açığını kapatmak için potansiyel bir çözüm olarak gördüğünü ve çalışmadan elde edilen sonuçların bunu desteklediğini belirtmektedirler.

Ortega ve Peri (2009), 14 OECD hedef ülkesi ve 74 OECD dışı kaynak ülke için kişi başı gelir, yatırım ve istihdam verileri ile göç arasındaki ilişkileri panel çekim modeli ile araştırmışlardır. 1980-2005 dönemi verilerinin kullanıldığı çalışmada, iki yönlü göç akımlarının kaynak ve hedef ülke arasındaki gelir farkı açıldıkça arttığı tespit edilmiştir. Bununla birlikte karşılıklı göç, hedef ülkeler daha sıkı göç yasaları uyguladıkça azalmaktadır. Öte yandan, ulaşılan bulgular, gelen göçün istihdam ve yatırımı artırdığını ancak yerli vatandaşların istihdamı üzerinde bir etkisi olmadığını göstermektedir. Çalışmanın ulaştığı bir diğer bulgu da göçün hedef ülkelerde kısa dönemde gelir artışına sebep olmasıdır.

Kim ve Cohen (2010) uluslararası göçün belirleyicilerini araştırdıkları çalışmalarında 1950- 2007 yıllarını kapsayan dönemde panel çekim modelini kullanmışlardır. Bu doğrultuda 17 batı ülkesinin göçmen girişi ve bu ülkelerin 13'ünden göçmen çıkışı verileri analize dahil edilmiştir. Yapılan analizler sonucunda elde edilen bulgular, göçmen girişlerinde en etkili değişkenlerin demografik ve coğrafi değişkenler olduğunu, sosyal ve tarihsel değişkenlerin daha az etkili olduğunu ortaya koymaktadır. Göçmen çıkışlarında ise en etkili değişkenler varış ülkesinin kökeni ve popülasyonu, bebek ölüm hızı ve başkentler arasındaki mesafe olarak ortaya konulmuştur. Çalışmada ayrıca varış ülkesindeki genç nüfus yapısının daha düşük göçmen girişleri ile ilişkiliyken kaynak ülkedeki genç nüfus yapısının daha yüksek göçmen girişleri ile ilişkili olduğu tespit 
edilmiştir. Kentleşmenin ise hem ana ülke hem de varış ülkesi için göçü artırdığı yönünde bulgular elde edilmiştir. Ülkenin denize kıyısının olmaması, ortak bir sınıra sahip olmak, aynı resmi dile sahip olmak, azınlık dilini paylaşmak ve sömürgeci bağlantılar ile uluslararası göç arasında da istatistiksel olarak anlamlı ancak niceliksel olarak daha zayıf düzeyde bir ilişki bulunmuştur.

Panel çekim modelini kullanarak göçlerin belirleyicilerini araştıran bir diğer çalışmada Lewer ve Berg (2008), 1991-2001 döneminde 16 OECD ülkesinde göçlerin ekonomik ve kurumsal belirleyicilerini analiz etmişlerdir. Elde edilen sonuçlar, literatür ile uyumlu olarak uzaklığın göçü açıklayan önemli bir faktör olduğunu göstermektedir. Araştırmacılar elde ettikleri göç sonuçlarını ülkeler arası ikili ticaret sonuçları ile karşılaştırarak insanların mallardan daha kolay şekilde sınırları geçtiği sonucuna ulaşmışlardır. Öte yandan çalışmada ülkelerdeki kurumsal çevredeki iyileşmenin göçün bir diğer belirleyicisi olduğu tespit edilmiştir. Çalışmadan elde edilen bir diğer sonuç daha eğitimli nüfusun daha fazla göç ettiğini ortaya koymaktadır.

Bove ve Elia (2017), göç ile oluşan kültürel çeşitliliğin ekonomik büyüme üzerindeki etkisini test etmişlerdir. Bu etki, 1960-2010 dönemi için karşılıklı göç verileri kullanılarak analiz edilmiştir. Ayrıca yapılan analiz 1960-2010 ve 19702010 alt dönemlerine ayrılarak tekrarlanmıştır. Araştırmacılar analizi 10 yıllık iki alt döneme ayırmalarının sebebini toplumun zaman içinde değişen yapısının daha iyi anlaşılması ve ekonomik büyümenin kısa dönemli dalgalanmalarının daha belirgin görülebilmesi olarak açıklamışlardır. Panel veri analizinin kullanıldığı çalışmada, göç hareketlerine ilişkin veriler kullanılarak oluşturulan göç endekslerinin hedef ülkelerde reel GSYH'yi artırdığ 1 tespit edilmiştir.

Docquier vd. (2011a) çalışmalarında, göçün kurumlar üzerindeki etkilerini dinamik panel veri analiz yöntemi ile gelişmekte olan ülkeler için araştırmışlardır. Analizlerde 1980-2005 arası dönem için beş y1llık dengesiz bir panel veri seti kullanılmıştır. Kurumsal yapıyı temsilen Freedom House'dan elde edilen ekonomik özgürlükler ve Polity IV'den elde edilen demokrasi endeksi kullanılmıştır. Göç verileri için, altı ana varış ülkesine (ABD, Kanada, Avustralya, Almanya, İngiltere ve Fransa) odaklanan Defoort (2008)'dan elde edilen tahminler kullanılmıştır. Çalışmadan elde edilen bulgular, göç ve beşeri sermayenin hem demokrasiyi hem de ekonomik özgürlüğü arttırdığını göstermektedir.

\section{Model ve Veri Seti}

Çalışmada göç, işsizlik ve kişi başına düşen gelir arasındaki uzun dönemli ilişkiler 27 OECD ülkesi ${ }^{3}$ için panel veri analiz yöntemi kullanılarak test edilmiştir. 20002016 dönemini kapsayan çalışmada yıllık veriler kullanılmıştır.

\footnotetext{
${ }^{3}$ Çalışmada 27 OECD ülkesi kullanılmıştır. Çalışma 2000-2016 dönemini kapsadığından 2000 yılından sonra OECD üyesi olan ülkeler çalışmaya dâhil edilmemiştir. Analizde kullanılan ülkeler: Avusturalya, Avusturya, Belçika, Kanada, Çek Cumhuriyeti, Danimarka, Finlandiya, Fransa,
} 
Analizde kullanılan model aşağıdaki gibidir:

$$
\ln m i g_{i t}=\alpha_{i}+\beta_{i t} \ln g d p+\gamma_{i t} \ln u n+\varepsilon_{i t}
$$

1 numaralı denklemde, $\mathrm{i}=1,2, \ldots, 27$ ve $\mathrm{t}=1,2, \ldots, 17$ 'yi göstermek üzere, lnmig, ülkeye yabancı uyruklu nüfus girişini yani göç düzeyini, lngdp kişi başına düşen geliri (sabit fiyatlarla, 2010 \$) ve Inun işsizlik oranını ifade etmektedir. Söz konusu değişkenler doğal logaritması alınarak doğrusallaştırılmıştır. Modelde kullanılan tüm veriler OECD veri tabanından elde edilmiş ve modelde kullanılan değişkenlere ilişskin açıklamalar Tablo 1'de sunulmuştur.

Tablo 1: Modelde Kullanılan Değişkenler

\begin{tabular}{|l|l|l|}
\hline Değişken adı & Değişken tanımlaması & Elde edildiği kaynak \\
\hline Ingdp & Kişi başına düşen gelir & OECD veri tabanı \\
\hline Inun & İşsizlik oranı (\%) & OECD veri tabanı \\
\hline Inmig & Göç Düzeyi & OECD veri tabanı \\
\hline
\end{tabular}

\subsection{Tanımlayıcı İstatistikler}

Analize başlamadan önce çalışmada kullanılan göç, işsizlik ve gelir değişkenlerine ait temel tanımlayıcı istatistiklere yer verilmiştir. Tablo 2'de sunulan tanımlayıcı istatistiklere göre, çalışmada 27 OECD ülkesi kullanılmış ve toplam gözlem sayısı 459'dur. Kişi başına düşen gelir logaritmik olarak en düşük 9.56 ve en yüksek 11.42 olup standart sapması $0.35^{\prime}$ dir. Bu sonuç analize konu olan ülkelerde kişi başına düşen gelir açısından bir yakınlaşma olduğunu ortaya koymaktadır. Ancak bu sonuç işsizlik oranı ve özellikle göç düzeyi açasından değişmektedir. İşsizlik ve göç düzeyinde standart sapmalar nispi olarak yüksektir ve bu sonuç işsizlik ve göç düzeyi açısından OECD ülkeleri arasında bir farklılaşma olduğunu ortaya koymaktadır.

Tablo 2: Tanımlayıcı İstatistikler

\begin{tabular}{|l|c|c|c|}
\hline & lngdp & lnun & Inmig \\
\hline Ortalama & 10.49958 & 1.801833 & 11.36762 \\
\hline Maksimum & 11.4207 & 3.26155 & 14.5167 \\
\hline Minimum & 9.56414 & 0.587787 & 7.21008 \\
\hline Std. Sapma & 0.346696 & 0.454014 & 1.377344 \\
\hline Gözlem Sayısı & 459 & 459 & 459 \\
\hline Ülke Sayısı & 27 & 27 & 27 \\
\hline
\end{tabular}

Almanya, Macaristan, İzlanda, İrlanda, İtalya, Japonya, Kore, Lüksemburg, Meksika, Hollanda, Yeni Zelanda, Norveç, Polonya, Portekiz, İspanya, İsveç, Türkiye, Birleşik Krallık ve Amerika Birleşik Devletleridir. 


\subsection{Ekonometrik Yöntem ve Analiz Sonuçları}

OECD ülkelerinde göç, işsizlik ve gelir arasındaki uzun dönemli ilişki Westerlund ve Edgerton (2007) tarafından geliştirilen LM Bootstrap eşbütünleşme testi ile araştırılmıştır. $\mathrm{Bu}$ bağlamda birinci veya ikinci nesil birim kök testilerinden hangilerinin kullanılacağına karar verebilmek için öncelikle seriler arasında yatay kesit bağımlılı̆̆ 1 olup olmadığ 1 araştırılmıştır. Ardından elde edilen yatay kesit bağımlılık testi sonuçlarına bağlı olarak birim kök testi tercihi yapılmıştır. Yatay kesit bağımlılık ve birim kök testi sonuçlarına göre uygun eşbütünleşme analizi belirlendikten sonra eşbütünleşme katsayılarının homojenliği test edilmiştir. Son olarak, değişkenler arasındaki uzun dönem ilişki tahmin edilmiştir.

\subsubsection{Yatay Kesit Bağımlılık Testi}

Çalışmada öncelikle değişkenler arasında yatay kesit bağımlılığı bulunup bulunmadığ1 test edilmiştir. Yatay kesit bağımlılığı, birimlerin yani ülkelerin herhangi birinde meydana gelen bir şoktan diğerlerinin de etkileneceği varsayımına dayanmaktadır. Paneli oluşturan değişkenler arasında yatay kesit bağımlılığı varsa bu durumu dikkate almadan elde edilen analiz sonuçları sağlıklı olmayacaktır. Ayrıca değişkenlerde yatay kesit bağımlılığının bulunması uygulanacak birim kök ve eşbütünleşme testi seçimini de etkilemektedir.

Yatay kesit bağımlılığın varlığını araştırmaya yönelik olarak Pesaran vd. (2008) tarafından önerilen Bias-Adjusted (Sapması Düzeltilmiş) LM test kullanılmıştır. Pesaran vd., (2008: 106), sapması düzeltilmiş LM testini Breusch ve Pagan (1980)' in Lagrange multiplier (LM) test istatistiğinin uyarlanmış hali olduğunu ifade etmektedir. Sapması düzeltilmiş LM testi ülke sayısının zaman boyutundan büyük olması durumunda $(\mathrm{N}>\mathrm{T})$ veya zaman boyutunun ülke sayısından büyük olduğu $(\mathrm{T}>\mathrm{N})$ durumlarda kullanılabilmektedir. Ancak bu yöntemde amaç, ülke sayısının zaman boyutundan büyük olduğu durumlarda ortaya çıkabilecek sapmaları düzeltmektir. Bu yöntem özellikle ülke sayısının zaman boyutundan büyük olduğu durumlarda Pesaran (2004) CD testine kıyasla daha tutarlı sonuçlar vermektedir. Sapması düzeltilmiş LM testi için hipotezler aşağıdaki şekilde oluşturulmaktadır:

$H_{0}=$ Yatay kesit bağımlılık yoktur

$H_{1}=$ Yatay kesit bağımlılık vardır

LMadj testi sonucunda elde edilen olasılık değerinin 0.05 'ten küçük olması durumunda $H_{0}$ hipotezi reddedilmekte ve bu durum ülkeler arasında yatay kesit bağımlılığının olduğunu göstermektedir. Öte yandan $H_{0}$ hipotezinin red edilememesi durumunda ülkeler arasında yatay kesit bağımlılığının olmadığını ortaya koymaktadır. Ülkeler arasında yatay kesit bağımlılı̆̆ının olup olmaması kullanılması gereken birim kök testlerine karar vermede belirleyici olmaktadır. 
Çalışmada 27 ülke 16 yıllık bir zaman boyutunda analiz edilmektedir. Bu nedenle yatay kesit bağımlılık testinde Sapması düzeltilmiş LM testi kullanılmış ve elde edilen sonuçlar Tablo 3 'de sunulmuştur.

Tablo 3: Yatay Kesit Bağımlılık Test Sonuçları

\begin{tabular}{ccccc}
\hline \multirow{2}{*}{ Test } & Lngdp & lnun & Inmig & Model \\
& & & & \\
\hline \multirow{2}{*}{ LMadj } & 4.091 & 4.071 & 9.950 & 20.402 \\
& $(0.000)$ & $(0.000)$ & $(0.000)$ & $(0.000)$ \\
\hline
\end{tabular}

Not: Olasılık değerleri parantez içinde gösterilmiştir.

Tablo 3'de hem değişkenler hem de model için yatay kesit bağımlılık test sonuçları yer almaktadır. Tablo 3'deki sonuçlara göre, gerek lngdp, lnun ve lnmig değişkenleri gerekse modelde yatay kesit bağımlılık olmadığını öne süren $\mathrm{H}_{0}$ hipotezi \%1 anlamlılık düzeyinde güçlü bir şekilde reddedilmiştir. Bu sonuç, gerek değişkenler arasında gerekse modelde yatay kesit bağımlılığı olduğunu göstermektedir. Kısaca, değişkenler arasında yatay kesit bağımlılığı vardır ve paneli oluşturan ülkelerden birinde meydana gelen bir şok diğer ülkeleri de etkilemektedir.

\subsubsection{Panel Birim Kök Testi}

Çalışmada paneli oluşturan OECD ülkeleri arasında yatay-kesit bağımlılığı tespit edildiğinden göç, işsizlik ve gelir değişkenlerinin birim kök içerip içermedikleri Pesaran (2007) tarafindan geliştirilen panel birim kök testi ile araştırılmıştır. Pesaran (2007) panel birim kök (CIPS) testine ilişkin hipotezler aşağıdaki şekildedir:

$$
\begin{aligned}
& H_{0}=\text { Seri durağan değildir (seri birim kök içermektedir) } \\
& H_{1}=\text { Seri durağandır (seri birim kök içermemektedir) }
\end{aligned}
$$

Hesaplanan CIPS testi istatistik değerleri, Pesaran (2007) tarafindan üretilen tablo kritik değerleriyle karşılaştırılarak serilerin birim kök içerip içermediğine karar verilmektedir. Buna göre eğer hesaplanan CIPS test istatistiği değeri tablo kritik değerinden büyükse $H_{0}$ hipotezi reddedilmekte ve serinin durağan olduğuna karar verilmektedir.

Çalışmada kullanılan serilere ait CIPS birim kök testi sonuçları Pesaran (2007) kritik tablo değerleriyle birlikte seviyesinde sabitli, trend ve sabitli modeller için Tablo 4'de sunulmuştur. 
Tablo 4: Seviyesinde Panel Birim Kök Test Sonuçları

\begin{tabular}{|c|c|c|}
\hline \multirow[b]{2}{*}{ Model } & \multicolumn{2}{|c|}{ Seviyesinde } \\
\hline & Trend + Sabit & Sabit \\
\hline Değişkenler & CIPS-testi & CIPS-testi \\
\hline Ingdp & -2.053 & -1.744 \\
\hline Inun & -1.664 & -1.244 \\
\hline Inmig & -2.109 & -1.878 \\
\hline & $\% 1-2.88$ & $\% 1-2,38$ \\
\hline Kritik Değerler & $\begin{array}{ll}\% 5 & -2.72\end{array}$ & $\% 5 \quad-2,20$ \\
\hline & $\% 10-2.63$ & $\% 10-2.11$ \\
\hline
\end{tabular}

Not: Gecikme sayıs1, k=1, Schwarz-Bayesian Bilgi Kriterine (SBC) göre belirlenmiştir. IPS için kritik değerler, Stata 15 programı tarafından önerilen kritik değerlerdir.

Tablo 4'te yer alan CIPS birim kök testi sonuçlarına göre, modelde yer alan lngdp, lnun ve lnmig değişkenlerine ilişkin hesaplanan CIPS istatistik değeri tablo kritik değerinden büyük olmadığından tüm değişkenler için seviyesinde $H_{0}$ hipotezi red edilememiştir. Buna göre, lngdp, lnun ve lnmig değişkenleri seviyesinde durağan değildir. Bir diğer ifadeyle lngdp, lnun ve lnmig değişkenleri birim kök içermektedir.

Serilerin seviyesinde durağan olamamaları yani birim kök içermeleri nedeniyle serilerin farkları alınmış ve gerek sabitli gerekse sabitli ve trendli modeller için birim kök testleri tekrar yapılmıştır. Serilerin birinci farkı alındıktan sonra hesaplanan CIPS istatistiği sonuçları Tablo 5'de sunulmuştur. CIPS birim kök test sonuçlarına göre, modelde yer alan lngdp, lnun ve lnmig değişkenlerine ilişkin hesaplanan CIPS istatistik değerleri tablo kritik değerlerinden büyük olduğundan tüm seriler için seviyesinde $H_{0}$ hipotezi \%1 seviyesinde red edilmiştir. Buna göre, lngdp, lnun ve lnmig serileri birinci farkında durağan olup birim kök içermemektedir.

Tablo 5: Birinci Farkında Panel Birim Kök Test Sonuçları

\begin{tabular}{|c|c|c|}
\hline \multirow{2}{*}{ Model } & \multicolumn{2}{|c|}{ 1. Farkında } \\
\hline & Trend + Sabit & Sabit \\
\hline Değișkenler & CIPS-testi & CIPS-testi \\
\hline lngdp & -2.917 & -2.750 \\
\hline Inun & -3.227 & -2.728 \\
\hline Inmig & -3.411 & -3.390 \\
\hline & $\begin{array}{ll}\% 1 & -2.88\end{array}$ & $\% 1 \quad-2,38$ \\
\hline Kritik Değerler & $\% 5 \quad-2.72$ & $\% 5 \quad-2,20$ \\
\hline & $\% 10-2.63$ & $\% 10-2.11$ \\
\hline
\end{tabular}

Not: Gecikme sayısı, k=1, Schwarz-Bayesian Bilgi Kriterine (SBC) göre belirlenmiştir. CIPS için kritik değerler, Stata 15 programı tarafından önerilen kritik değerlerdir.

Çalışmada kullanılan tüm seriler (lngdp, lnun ve lnmig) seviyesinde birim kök içermekte iken birinci farkları alındığında ise durağan hale gelmişlerdir. Serilerin 
birinci dereceden durağan oluşu değişkenler arası muhtemel eşbütünleşme ilişkisinin varlığının araştırılmasını zorunlu kılmaktadır. Bu nedenle devam eden kısımda değişkenler arasında muhtemel eşbütünleşme ilişkileri analiz edilmiştir.

\subsubsection{Homojenlik Testleri}

Panel veri analizi kapsamında hesaplanacak eğim katsayılarının homojen olup olmadığını test etmek amacıyla Pesaran ve Yamagata (2008) tarafindan geliştirilen $\tilde{\Delta}$ (delta) testi kullanılmıştır.

$$
\begin{aligned}
& \tilde{\Delta}=\sqrt{N}\left(\frac{N^{-1} \tilde{S}-k}{\sqrt{2 k}}\right) \\
& \tilde{\Delta}_{a d j}=\sqrt{N}\left(\frac{N^{-1} \tilde{S}-E\left(\tilde{\mathrm{z}}_{i T}\right)}{\sqrt{\operatorname{Var}\left(\tilde{\mathrm{z}}_{i T}\right)}}\right)
\end{aligned}
$$

Pesaran ve Yamagata (2008) homojenlik testi kapsaminda denklem 2 ve 3'de yer verilen delta istatistiği ve düzeltilmiş delta istatistikleri hesaplanmaktadır. Delta istatistiği büyük örneklemler için daha doğru sonuçlar verirken, düzeltilmiş delta istatistiği ise küçük örneklemler için daha doğru sonuçlar vermektedir.

Delta ve düzeltilmiş delta homojenlik testlerine ilişkin hipotezler aşağıdaki şekildedir:

$H_{0}=$ Eğim katsayıları homojendir

$H_{1}=$ Eğim katsayıları homojen değildir

Çalışmada kullanılan değişkenlere ilişkin eğim katsayıları homojenlik test sonuçları Tablo 6'da sunulmuştur. Test sonuçlarına göre, gerek delta gerekse düzeltilmiş delta istatistikleri eğim katsayılarının homojen olduğunu gösteren $H_{0}$ hipotezini $\% 1$ seviyesinde güçlü bir şekilde reddetmektedir. Buna göre eğim katsayıları homojen değildir. Eğim katsayıları homojen olmadığı için uzun dönemli katsayıların hesaplanmasında heterojen sonuçlar elde etmeye olanak sağlayan eşbütünleşme tahmincileri kullanılmıştır.

Tablo 6: Eğim Katsayıları Homojenliği Testleri

\begin{tabular}{lcc}
\hline \multicolumn{1}{c}{ Testler } & İstatistik & Olasılık Değeri \\
\hline$\tilde{\Delta}$ & 13.930 & 0.000 \\
$\tilde{\Delta}_{a d j}$ & 15.795 & 0.000 \\
\hline
\end{tabular}




\subsubsection{Eşbütünleşme Testi}

Çalışmada kullanılan değişkenler arasında gerek yatay kesit bağımlılı̆̆ın olması gerekse değişkenlere ilişkin hesaplanan eğim katsayılarının homojen olmaması nedeniyle Westerlund ve Edgerton (2007) tarafindan geliştirilen ikinci nesil eşbütünleşme testi kullanılmıştır. Bu eşbütünleşme testini kullanmanın bir diğer gerekçesi ise çalışmada nispi olarak küçük zaman boyutuna sahip olunmasıdır.

Westerlund ve Edgerton (2007), McCoskey ve Kao (1998)'in Lagrange çarpanı testine dayanan bir panel eşbütünleşme testi (LM Bootstrap eşbütünleşme testi) önermişlerdir. Bu test yatay kesit birimleri arasındaki bağımlılığı dikkate almakta ve küçük örneklemler için iyi sonuçlar vermektedir (Westerlund ve Edgerton, 2007: 185).

Westerlund ve Edgerton (2007) eşbütünleşme testinde hipotezler aşağıdaki şekildedir:

\section{$H_{0}=\sigma_{i}^{2}=0$ (tüm i ler için seriler arasında eşbütünleşme vardır) \\ $H_{1}=\sigma_{i}^{2}>0$ (bazı i ler için seriler arasında eşbütünleşme yoktur)}

Westerlund ve Edgerton (2007) LM Bootstrap eşbütünleşme test sonuçları Tablo 7'de sunulmuştur. Tablo 7'de yer alan sonuçlara göre, değişkenler arasında uzun dönemli bir ilişki olduğun öne süren $H_{0}$ hipotezi \%1 seviyesinde güçlü bir biçimde red edilmiştir. Diğer bir deyişle, Westerlund ve Edgerton (2007) eşbütünleşme test sonuçları değişkenler arasında uzun dönemli bir ilişki olmadığını ortaya koymaktadır.

Tablo 7: LM Bootstrap Eşbütünleşme Testi Sonuçları

\begin{tabular}{ccc}
\hline Test Adı & İstatistik & Olasılık Değeri \\
\hline LM Bootstrap & 94.397 & 0.000 \\
\hline
\end{tabular}

\subsubsection{Değişkenlerin Katsayılarının Hesaplanması}

Çalışmada kullanılan değişkenler arasında eşbütünleşik bir ilişkinin çıkmaması nedeniyle değişkenler arasındaki ilişkinin yönü ve büyüklügüüün tespiti için değişken katsayıları Eberhardt ve Bond (2009), Eberhardt ve Teal (2011) tarafından geliştirilen "genişletilmiş ortalama grup tahmincisi" (AMG: Augmented Mean Group Estimator) yöntemi ile tahmin edilmiştir. AMG tahmincisini kullanmanın çok sayıda avantajı bulunmaktadır. Birinci olarak, AMG tahmincisi modelde kullanılan değişkenlerin durağanlık derecelerinin aynı olması şartını aramamaktadır. İkinci olarak AMG tahmincisinde değişkenlerin eşbütünleşik olma zorunluluğu bulunmamaktadır. Üçüncü olarak AMG tahmincisi yatay kesitler arasındaki bağımlılığı dikkate almamaktadır. Son olarak AMG tahmincisi kullanılarak her bir kesit (ülke) için farklı katsayılar tahmin edilebilme firsatı sunmaktadır (Eberhardt ve Bond, 2009: 4-6). 
Çalışmada sunduğu avantajlardan dolayı AMG tahmincisi kullanılarak değişkenlere ilişkin katsayılar 27 OECD ülkesi için tahmin edilmiştir. AMG tahmincisinden elde edilen sonuçlar sabitli ve trendli model için Tablo 8'de ve sabitli model için Tablo 9'da sunulmuştur.

Tablo 8: Sabitli ve Trendli Model AMG Sonuçları

\begin{tabular}{lcc}
\hline \multicolumn{1}{c}{ Değişkenler } & Katsayı & Olasılık Değeri \\
\hline Inun & -0.530 & 0.000 \\
Ingdp & -0.610 & 0.501 \\
Sabit & 0.099 & 0.984 \\
Trend & 0.007 & 0.591 \\
\hline Wald istatistiği & 20.59 & 0.001 \\
\hline
\end{tabular}

Tablo 8'de yer alan sabitli ve trendli AMG tahmin sonuçlarına göre, işsizlik oranı \%1 anlamlılık seviyesinde göç üzerinde negatif bir etkiye sahiptir. Buna karşılık, kişi başına düşen gelirin katsayısı negatif olup istatistiksel olarak anlamlı değildir. Ayrıca modelde yer alan trend istatistiksel olarak anlamsızdır. Modelin bir bütün olarak anlamlı olduğunu gösteren Wald istatisiği \%1 seviyesinde anlamlı tespit edilmiştir. Tahmin edilen modelde trend değişkeninin anlamsız olması nedeniyle model, trend çıkarılarak tekrar tahmin edilmiş olup, tahmin sonuçları Tablo 9'da sunulmuştur.

Tablo 9: Sabitli Model AMG Sonuçları

\begin{tabular}{lcc}
\hline \multicolumn{1}{c}{ Değişkenler } & Katsayı & Olasılık Değeri \\
\hline Inun & -0.307 & 0.005 \\
Ingdp & 1.054 & 0.001 \\
Sabit & 0.099 & 0.984 \\
\hline Wald istatistiği & 13.60 & 0.001 \\
\hline
\end{tabular}

Tablo 9'da yer alan sabitli model AMG tahmin sonuçlarına göre, işsizlik oranı göç üzerinde negatif ve \%1 seviyesinde istatistiksel olarak anlamlı bir etkiye sahiptir. Öte yandan, kişi başına düşen gelirin katsayısı pozitif olup \%1 seviyesinde istatistiksel olarak anlamlıdır. Ayrıca modelin bir bütün olarak anlamlı olduğunu gösteren Wald istatisiği \%1 seviyesinde anlamlı tespit edilmiştir.

Çalışmada değişkenlerin doğal logaritması alınarak kullanıldığından elde edilen AMG katsayılarını esneklik olarak yorumlamak mümkündür. Bu sonuçlara göre, işsizlik oranında meydana gelen \%1'lik artış, OECD ülkelerinde bu ülkelere gelen göçü yaklaşık \%0,3 azaltmaktadır. Yani OECD ülkelerinde olası işsizlik artışları, ilgili ülkelere olan göç akımlarını yavaşlatmaktadır. Diğer taraftan kişi başına düşen gelirin \%1 oranında artması, OECD ülkelerine gelen göçü yaklaşık \%1 oranında artırmaktadır. Bu bağlamda göç kararının verilmesinde OECD ülkelerinin gelir düzeylerinin önemli bir pozitif etken olduğu söylenebilir. Kısaca, OECD 
ülkelerinde yaşanacak refah artışlarına bağlı olarak gelecekte OECD ülkelerine göç akımlarının artması beklenebilir.

\section{Sonuç ve Değerlendirme}

İktisatçılar açısından bir üretim faktörü olan göçmenler özellikle işgücü açığı olan ülke ekonomileri için büyük önem taşımaktadır. Göçmenlerin sahip olduğu farklı bilgi ve beceriler üretim sürecinde ev sahibi ülke için son derece değerli olsa da ev sahibi ülkenin işgücü tarafından işini kaybedeceği ya da ücretleri düşüreceği endişesiyle bu durum farklı değerlendirilebilmektedir. Beklentiler göçün gelişmekte olan ülkelerden gelişmiş ülkelere doğru yönelmesi şeklinde olsa da her bireyin göç kararını etkileyen iten ve çeken faktörler ile göç maliyetlerinin farklı olması nedeniyle bu durum her zaman gerçekleşmeyebilir. Bu nedenle ülkelere özgü iten ve çeken faktörlerin tespiti son derece önemlidir.

Göçün iten ve çeken makroekonomik göstergelerini test etmek amaciyla bu çalışmada göç, işsizlik ve kişi başına düşen gelir arasındaki ilişkiler 2000-2016 döneminde panel veri analiz yöntemi kullanılarak test edilmiştir. Dünyada en fazla göç alan ülkelerin de aralarında bulunduğu 27 OECD ülkesinde göçü iten ve göçü çeken temel iki makroekonomik göstergenin göç üzerindeki etkisi analiz edilmiştir. $\mathrm{Bu}$ amaçla çalışmada öncelikle göç, işsizlik ve kişi başına düşen gelir serilerinin yatay kesit bağımlılık gösterip göstermediklerine sapması düzeltilmiş LM testi kullanılarak bakılmıştır. Seriler arasında yatay kesit bağımlılı̆̆ın tespit edilmesiyle birlikte serilerin birim kök içerip içermediği ikinci nesil birim kök testlerinden CIPS testi kullanılarak analiz edilmiştir. Gerek seriler arasında yatay kesit bağımlılığın tespiti gerekse serilerin birinci dereceden durağan olmaları nedeniyle eşbütünleşme testleri yapılmış ve ikinci nesil eşbütünleşme testlerinden LM bootstrap testi kullanılmıştır. Seriler arasında eşbütünleşik bir ilişkinin çıkmaması nedeniyle seriler arasındaki ilişkinin yönü ve büyüklügünün tespiti $\mathrm{AMG}$ yöntemi ile tahmin edilmiştir.

Yapılan analiz sonucunda elde edilen sonuçlara göre, işsizlik oranı göç üzerinde negatif ve \%1 seviyesinde istatistiksel olarak anlamlı bir etkiye sahiptir. Öte yandan, kişi başına düşen gelirin katsayısı pozitif olup \%1 seviyesinde istatistiksel olarak anlamlıdır. Çalışmada değişkenlerin doğal logaritması alınarak kullanıldığından elde edilen AMG katsayılarını aşağıdaki şekilde esneklik olarak yorumlamak mümkündür. Analiz sonuçlarına göre, işsizlik oranında meydana gelen \%1'lik artış, OECD ülkelerinde bu ülkelere gelen göçü yaklaşık \%0,3 azaltmaktadır. Bu bağlamda OECD ülkelerinde olası işsizlik artışları, ilgili ülkelere göç akımlarını yavaşlatmaktadır. Diğer taraftan kişi başına düşen gelirin \%1 oranında artması, OECD ülkelerine gelen göçü yaklaşık \%1 oranında artırmaktadır. $\mathrm{Bu}$ sonuçtan yola çıkarak göç kararının verilmesinde OECD ülkelerinin gelir düzeylerinin önemli bir pozitif etken olduğu söylenebilir. Kısaca OECD ülkelerinde yaşanacak refah artışlarına bağlı olarak gelecekte OECD ülkelerine göç akımlarının artması beklenebilir. Çünkü analiz sonuçları OECD ülkelerinde işsizlik oranlarının itici faktör, refah seviyesinin ise çekici faktör olduğunu ortaya koymaktadır. 
Çalışmadan elde edilen bu sonuçlar, Ravenstein'in teorisinde olduğu gibi göçün belli kanunlar çerçevesinde bir ülkeden diğerine gitmediğini her ülkenin kendine özgü koşullarının göç akımlarını etkilediğini ortaya koymaktadır. Ayrıca işgücü açığını kapatmak için göç almak veya ülkesine yönelen göç akımlarının olumsuz etkilerinden kurtulmak için tek reçetenin bulunmadığını göstermektedir. Sonuç olarak göç olayı, coğrafya, sosyoloji, psikoloji vb. çok sayıda faktör tarafindan belirlenen bir olgu olduğundan göçle ilgili olarak politika uygulayıcılarının ülkelerine özgü bireysel özellikleri dikkate alarak politika geliştirmeleri önem arz etmektedir.

\section{Kaynakça}

Birleşmiş Milletler (2017). International Migration Report 2017.

Bonin, Holger (2005). Wage and Employment Effects of Immigration to Germany: Evidence from a Skill Group Approach. IZA DP No. 1875.

Borjas, George J. (2001). Does Immigration Grease the Wheels of the Labor Market? Brookings Papers on Economic Activity, 32(1), 69-134.

Boubtane, Ekrame vd. (2013). Immigration, Unemployment and GDP in the Host Country: Bootstrap Panel Granger Causality Analysis on OECD Countries. Economic Modelling, 33(2013), 261-269.

Bove, Vincenzo ve Elia, Leandro (2017). Migration, Diversity, and Economic Growth. World Development, 89, 227-239.

Breusch, P. S. ve Pagan, A. R. (1980). The Lagrange Multiplier Test and its Applications to Model Specification in Econometrics. Review of Economic Studies, 11(7), 239-253.

Di Maria, Corrado ve Lazarova, Emiliya A. (2012). Migration, Human Capital Formation, and Growth: An Empirical Investigation. World Development, 40(5), 938-955.

Docquier, Frédéric vd. (2011a). Emigration and Democracy", IZA Discussion Paper No. 5496, http://ftp.iza.org/dp5496.pdf (Erişim Tarihi: 20.06.2019).

Docquier, Frédéric vd. (2011b). The Labor Market Effects of Immigration and Emigration in OECD Countries. IZA DP No. 6258.

Dustmann, Christian vd. (2005). The Impact of Immigration on the British Labor Market. The Economic Journal, 115(507), 324-341.

Eberhardt, M. ve Teal, F. (2011). Econometrics for Grumblers: A New look at the Literature on Cross-Country Growth Empirics, Journal of Economic Surveys, 25(1), 109-155.

Eberhardt, Markus ve Bond, Stephen (2009). Cross-section Dependence in Nonstationary Panel Models: A Novel Estimator. MPRA Paper No: 17692. 
Grogger, J. ve Hanson, G. H. (2011). "Income Maximization and the Selection and Sorting of International Migrants. Journal of Development Economics, 95, 4257.

Islam, Asadul (2007), "Immigration Unemployment Relationship: The Evidence from Canada", Australian Economic Papers, March, 52-66.

Jean, Sebastien ve Jimenez, Miguel (2011). The Unemployment Impact of Immigration in OECD Countries. European Journal of Political Economy, 27, 241-256.

Karemera, D., vd. (2000). A Gravity Model Analysis of International Migration to North America. Applied Economics, 32(13),1745-1755.

Kim, Keuntae ve Cohen, Joel E. (2010). Determinants of International Migration Flows to and from Industrialized Countries: A Panel Data Approach Beyond Gravity. International Migration Review, 44(4), 899- 932.

Lee, E.S. (1966). A Theory of Migration. Demography, 3(1), 47-55.

Lewer, Joshua J. ve Berg, Hendrik Van den, (2008). A Gravity Model of Immigration. Economics Letters, 99, 164-167.

Mayda, Anna M. (2007). International Migration: A Panel Data Analysis of the Determinants of Bilateral Flows. Discussion Paper Series, CDP No 07/07.

Morley, Bruce (2006). Causality Between Economic Growth and Immigration: An ARDL Bounds Testing Approach. Economics Letters, 90(1), 72-76.

Neumayer, E. (2005). Bogus Refugees? The Determinants of Asylum Migration to Western Europe. International Studies Quarterly, 49, 389-409.

OECD (2018), International Migration Outlook, OECD Publishing, Paris.

OECD International Migration Database, http://www.oecd.org/migration/mig/oecdmigrationdatabases.htm

Ortega, Francesc ve Peri, Giovanni (2009). The Causes and Effects of International Migrations: Evidence from OECD Countries 1980-2005. NBER Working Paper Series, Working Paper 14833.

Ortega, Javier and Verdugo, Gregory (2014). The Impact of Immigration on the French Labor Market: Why so different? Labor Economics, 29(C), 14-27.

Pesaran, Hashem M. (2004). General Diagnostic Tests for Cross Section Dependence Panels. CESifo Working Paper Series No: 1229.

Pesaran, Hashem M. (2007). A Simple Panel Unit Root Test in The Presence of Cross-Section Dependence. Journal of Applied Econometrics, 22 (2), 265-312.

Pesaran, M. Hasheem, vd. (2008). A Bias-Adjusted LM Test for Error CrossSection Independence. Econometrics Journal, 11, 105-127. 
Pesaran, M. Hashem ve Yamagata, T. (2008). Testing Slope Homogeneity in Large Panels. Journal of Econometrics, 142 (1), 50-93.

Petersen, William (1958). A General Typology of Migration. American Sociological Review, 23(3), 256-266.

Pischke, Jörn-Steffen ve Velling, Johannes (1997). Employment Effects of Immigration to Germany: An Analysis Based on Local Labor Markets. The Review of Economics and Statistics, 79(4) 594-604.

Ravenstein, E. G. (1885). The Laws of Migration. Journal of the Statistical Society, 48(2), 167-235.

Shan vd. (1999). Immigration and Unemployment: New Evidence from Australia and New Zealand. International Review of Applied Economics, 13(2), 253-260.

Steinhardt, Max Friedrich (2011). The Wage Impact of Immigration in GermanyNew Evidence for Skill Groups and Occupations. The B.E. Journal of Economic Analysis \& Policy, 11(1), 1-33.

Stouffer, Samuel A. (1940). Intervening Opportunities: A Theory Relating Mobility and Distance. American Sociological Review, 5(6), 845-867.

Westerlund, Joakim ve Edgerton, David (2007). A Panel Boostrap Cointegration Test. Economic Letters, 97(3), 185-190.

Zipf, George Kingsley (1946). The $\mathrm{P}_{1} \mathrm{P}_{2} / \mathrm{D}$ Hypothesis: On the Intercity Movement of Persons. American Sociological Review, 11(6), 677-686. 